\title{
Efektivitas Kombinasi Ekstrak Kunyit (Curcuma Domestica Val) dan Madu Terhadap Ulkus Lambung Mencit BALB/c Akibat Pemberian Aspirin Secara Mikroskopis
}

\author{
Sarianti Br Simbolon ${ }^{1}$, Yusticia Katar ${ }^{2}$, Selfi Renita Rusjdi ${ }^{3}$
}

\begin{abstract}
Abstrak
Aspirin adalah golongan OAINS dengan efek samping yang paling sering adalah ulkus lambung. Kunyit (Curcuma Domestica val) dan madu memilki aktivitas dalam mencegah ulkus lambung. Tujuan penelitian ini adalah menentukan apakah kombinasi ekstrak kunyit dan madu mempunyai efektivitas yang lebih baik dalam mengurangi ulkus lambung akibat pemberian aspirin dibandingkan ekstrak kunyit atau madu saja pada mencit BALB/c secara mikroskopis. Penelitian eksperimental post test only control group design telah dilakukan dari Januari 2016 sampai Januari 2017 menggunakan 30 ekor mencit yang semua diberikan aspirin $5.2 \mathrm{mg} / \mathrm{gBB}$ untuk menyebabkan ulkus pada lambung, kemudian dibagi menjadi kelompok kontrol $(\mathrm{K})$ hanya diberi aspirin, perlakuan 1 (P1) diberikan larutan ekstrak kunyit dosis $10 \mathrm{mg} / \mathrm{gBB}$, (P2) madu $0.04 \mathrm{ml} / \mathrm{gBB}$, (P3) kunyit $10 \mathrm{mg} / \mathrm{gBB}+$ madu $0.04 \mathrm{ml} / \mathrm{gBB}$, (P4) Kunyit 30 $\mathrm{mg} / \mathrm{gBB}+$ madu $0.12 \mathrm{ml} / \mathrm{gBB}$, diberikan selama 3 hari per oral. Hari ke-4 mencit di eutanasia menggunakan eter, kemudian diperiksa secara mikroskopis. Hasil pada kelompok P1, P2, P3 dan P4 dibandingkan dengan $\mathrm{K}$ dan begitu juga P4 dibandingkan dengan P3, P2, P1 menunjukkan hasil yang signifikan $(p<0.05)$, sedangkan $P 3$ dibandingkan dengan P2 dan P1 menunjukkan hasil tidak signifikan $(p>0.05)$. Simpulan studi ini adalah kelompok P4 memiliki efektivitas lebih baik dalam mengurangi ulkus lambung mencit dibandingkan dengan P3, P2 dan P1.
\end{abstract}

Kata kunci: aspirin, kunyit (Curcuma domestica val), madu, ulkus lambung

\section{Abstract}

Aspirin is the group NSAID with gastric ulcers as the most common side effects. Turmeric (Curcuma Domestica val) and honey has an activity in preventing gastric ulcers. The objective of this study was to determine whether the combination tumeric extract and honey have the effectivess in reducing gastric ulcers induced aspirin compared tumeric extract or honey only in mice BALB/C microscopically. Experimental research post test only control group design was conducted in January 2016 - January 2017 using 30 mice were all given aspirin 5.2 mg/gBW caused ulcers gaster, then divided into a control group was only given aspirin, treatment $1(P 1)$ is given a solution of turmeric extract dose of $10 \mathrm{mg} / \mathrm{gBW}$, (P2) honey $0.04 \mathrm{ml} / \mathrm{gBW}$, (P3) tumeric $10 \mathrm{mg} / \mathrm{gBW}+$ honey $0.04 \mathrm{ml} / \mathrm{gBW}$, (P4) turmeric 30 $\mathrm{mg} / \mathrm{gBW}+$ honey $0.12 \mathrm{ml} / \mathrm{gBW}$, administered for 3 days per oral. Day 4 mice were euthanized using ether then examined microscopically. The results of the group $P 1, P 2, P 3$ and $P 4$ compared with $K$ and so is $P 4$ compared to $P 3$, $P 2$ and $P 1$ showed significant results $(p<0.05)$, whereas $P 3$ compared to $P 2$ and $P 1$ shows the result was not significant ( $p>0.05)$, The conclusion is the $P 4$ group had better effictiveness in reducing gastric ulcer mice compared $P 3, P 2$ and $P 1$.

Keywords: aspirin, turmeric (Curcuma domestica val), honey, gastric ulcers

Affiliasi penulis: 1. Prodi Pendidikan Dokter (Fakultas Kedokteran Universitas Andalas Padang (FK Unand), 2. Laboratorium Farmakologi Fakultas Farmasi Unand, 3 Bagian Patologi Anatomi FK Unand
Korespondensi: Sarianti $\mathrm{Br}$ Simbolon, Email: sariantisimbolon@gmail.com Telp: 085271591137 


\section{PENDAHULUAN}

Aspirin adalah golongan Obat Anti Inflamasi Non-Steroid (OAINS), yang memiliki efek analgetik, antipiretik dan antiinflamasi yang bekerja secara perifer. Obat ini digunakan pada terapi simtomatis penyakit rematik (osteoatritis, atritis gout) dalam menghilangkan atau mengurangi rasa nyeri. OAINS merupakan obat yang paling sering dipakai, diperkirakan lebih dari 30 juta orang diseluruh dunia mengonsumsi OAINS dalam sehari dan disebut sebagai obat bebas. ${ }^{1}$

Obat ini bagaikan pedang bermata dua yaitu selain memiliki efektifitas yang sudah tidak diragukan lagi dalam mengatasi rasa nyeri, inflamasi dan menurunkan demam juga dapat menimbulkan efek samping utama dan paling sering terjadi pada saluran cerna berupa erosi, ulserasi, perforasi sampai perdarahan yang bahkan mengakibatkan kematian. ${ }^{2}$

Hasil penelitian menunjukkan bahwa penghambatan enzim COX-2 paling berperan dalam fungsi OAINS sebagai anti inflamasi. Enzim COX-1 dilambung bekerja merangsang pembentukan prostaglandin, yang berfungsi sebagai pelindung mukosa lambung dan mengatur aliran darah ke lambung, sehingga penghambatan kerja enzim COX-1 oleh OAINS akan menimbulkan efek samping. Penghambatan sintesis prostaglandin akan mengakibatkan pertahanan mukosa saluran cerna akan terganggu, sehingga terjadi penurunann sekresi mukus dan bikarbonat serta berkurangnya aliran darah ke mukosa, yang mengakibatkan terhambatnya proses perbaikan epitel dan perubahan pada proses seluler lainnya yang pada akhirnya akan menimbulkan kerusakan mukosa saluran cerna. ${ }^{3}$

Dalam mengurangi terjadinya ulkus lambung dilakukan usaha diantaranya: harus menggunakan OAINS dengan indikasi yang tepat, tidak digunakan lebih dari satu preparat OAINS, hindari penggunaan dalam jangka panjang, jangan dikombinasikan dengan kortikosteroid, dan dosis yang digunakan disesuaikan dengan tingkat nyeri. Usaha lain untuk mengurangi toksisitas OAINS telah dicoba beberapa strategi dalam pemakaian dengan menggunakan (1) Antasida (2) Antagonis $\mathrm{H}-2$ reseptor (3) Proton Pump Inhibitor (PPI) (4) Sukralfat (5) Analog prostaglandin (misoprostol) (6) Diet rendah lemak. ${ }^{4}$
Efek samping OAINS terhadap saluran cerna belum secara tuntas terselesaikan. Strategi yang digunakan selalu ada kekurangan dan kelebihan. Karena efek samping tidak bisa dihindari, sehingga muncul usaha untuk mengurangi efek samping yang lebih aman yaitu dengan menggunakan obat tradisional atau bahan alam. Obat tradisional atau bahan alam yang telah diteliti dan terbukti khasiat dalam mengurangi kerusakan lambung adalah menggunakan kunyit, madu, temulawak, alpukat, jambu biji, dan beras hitam. OAINS digolongkan menjadi OAINS potensi ringan, sedang dan berat. Penelitian ekstrak kunyit atau madu saja bisa untuk mengatasi efek samping OAINS potensi ringan sampai sedang, sedangkan untuk OAINS potensi tinggi diperlukan obat tradisional atau bahan alam yang memiliki efektifitas lebih baik dalam mengurangi ulkus lambung. ${ }^{5}$

Berdasarkan hal diatas, maka muncul pertanyaan apakah kombinasi larutan ekstrak kunyit dan madu efeknya akan meningkat dalam menghambat atau mengurangi ulkus lambung akibat pemberian aspirin dibandingkan hanya menggunakan ekstrak kunyit atau madu saja.

Pada penelitian yang dilakukan Adita (2010) menunjukkan hasil yang signifikan. Ekstrak kunyit dapat memproteksi mukosa lambung dengan meningkatkan sekresi mukus dan mempunyai efek vasodilator sehingga kunyit dapat meningkatkan pertahanan mukosa lambung. Adapun kandungan zat aktif kunyit yang dapat melindung mukosa lambung adalah kurkuminoid dan minyak atsiri. ${ }^{6}$

Penelitian yang dilakukan Mustaba (2012) menunjukkan hasil yang signifikan. Madu terbukti secara mikroskopis memiliki efek proteksi terhadap lambung berupa pengurangan derajat kerusakan sel lambung. Madu diketahui memiliki kandungan asam organik, mineral, vitamin, serta kaya akan zat-zat aktif yang berperan sebagai antioksidan yang dapat melindungi jaringan dari kerusakan dengan merangsang regenerasi jaringan. ${ }^{7}$

Berdasarkan latar belakang tersebut, perlu dibuktikan apakah efektivitas dari kombinasi larutan ekstrak kunyit dan madu akan meningkat dalam mengurangi ulkus pada lambung mencit BALB/c yang timbul akibat pemberian aspirin, dibandingkan hanya 
menggunakan ekstrak kunyit atau madu saja. Selain dari itu diharapkan kombinasi larutan ekstrak kunyit dan madu dapat digunakann sebagai profilaksis dalam mencegah efek samping pada saluran cerna yang dapat ditimbulkan akibat penggunaan OAINS, dalam bentuk minuman segar yang enak rasanya.

\section{METODE}

Penelitian post test only control group design ini dilakukan di Laboratorium Farmakologi Fakultas Farmasi Universitas Andalas dan Laboratorium Patologi Anatomi Fakultas Kedokteran Universitas Andalas pada bulan Januari 2016 - Januari 2017 Jumlah sampel pada penelitian ini menggunakan 30 mencit BALB/c yang dibagi menjadi 5 kelompok, yaitu kelompok K (Aspirin 5,2 mg/20gBB), P1(Aspirin 5,2 $\mathrm{mg} / 20 \mathrm{gBB}+$ Kunyit $10 \mathrm{mg} / 20 \mathrm{gBB}$ ), P2 (Aspirin 5,2 $\mathrm{mg} / \mathrm{BB} 20 \mathrm{~g}+$ Madu 0,04 ml/20gBB), P3 (Aspirin 5,2 $\mathrm{mg} / 20 \mathrm{gBB}+$ Kombinasi Kunyit 10 mg/20gBB dan Madu dosis 0,04 ml/20gBB), P4 (Aspirin 5,2 $\mathrm{mg} / 20 \mathrm{gBB}+$ Kombinasi Kunyit 30 mg/20GBB dan madu 0,12 ml/20gBB). Percobaan dilakukan selama 3 hari berturut-turut dimana pemberian larutan ekstrak kunyit, madu, dan kombinasi larutan ekstrak kunyit dan madu diberikan 1 jam setelah pemberian aspirin. Setelah 3 hari perlakuan diberhentikan. Semua mencit di euthanasia dengan menggunakan eter, setelah itu dilakukan laparotomi kemudian dilanjutkan pembuatan slide sediaan histopatologi untuk dilihat secara mikroskopis. Pengamatan dilakukan dengan menilai integritas mukosa lambung berdasarkan modifikasi kriteria Barthel Manja. Data dianalisis dengan Uji Oneway ANOVA dan Kruskal-Wallis Test.

\section{HASIL}

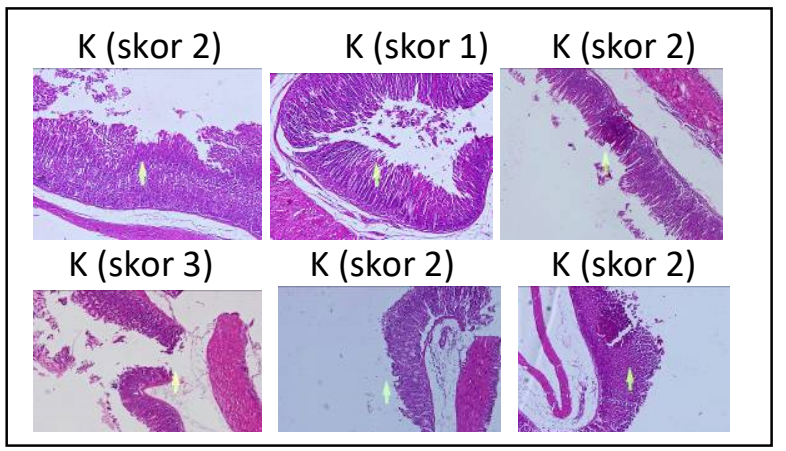

Gambar 1. Kelompok kontrol (K)
Gambar 1 menunjukkan seluruh mukosa lambung mencit rerata mengalami ulkus, dimana terlihat epitel sudah terlepas mencapai sebagian yang berarti kerusakan sudah mencapai setengah lapisan epitel atau yang disebut erosi dan ulserasi. Pada gambar tampak terjadi deskuamasi epitel, erosi dan ulserasi epitel mukosa lambung dan tidak ada mukosa yang normal.

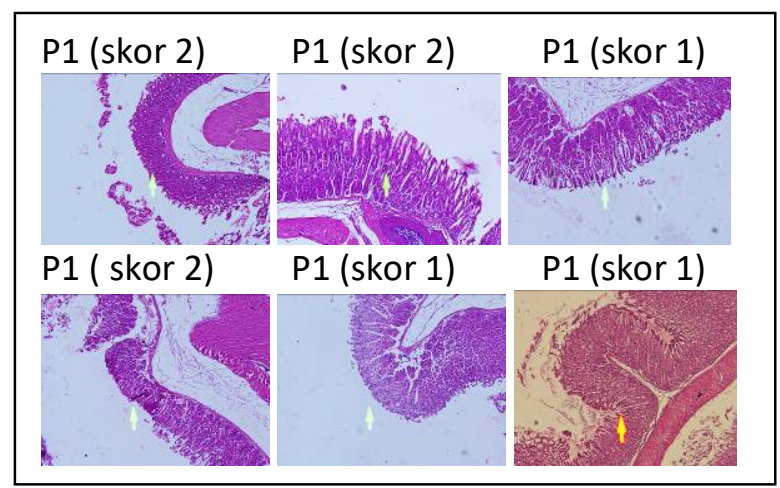

Gambar 2. Kelompok perlakuan 1 (P1)

Gambar 2 menunjukkan lapisan mukosa lambung dari keenam mencit terlihat ulkus yang sudah mulai berkurang, dibandingkan kelompok kontrol.

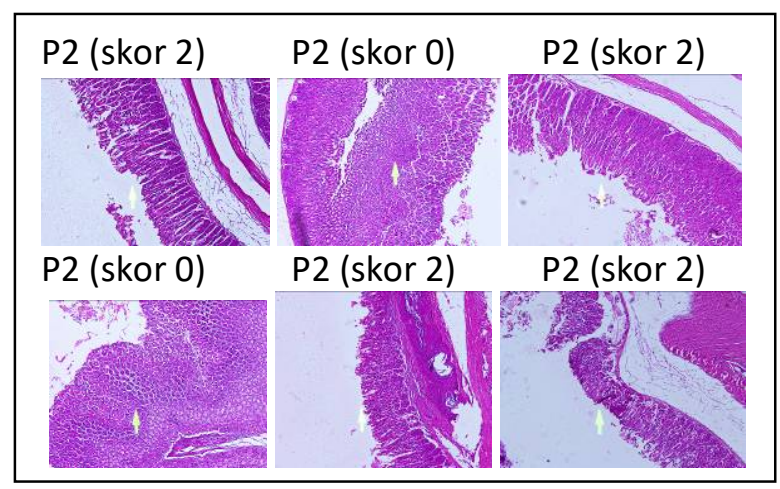

Gambar 3. Kelompok perlakuan 2 (P2)

Gambar 3 menunjukkan dari keenam gambaran mukosa lambung mencit memperlihatkan ulkus mukosa lambung, yang sudah mengalami pengurangan kerusakan dibandingkan dengan kelompok $\mathrm{K}$ dan hasil $\mathrm{P} 2$ tidak terlalu berbeda dari kelompok P1. 


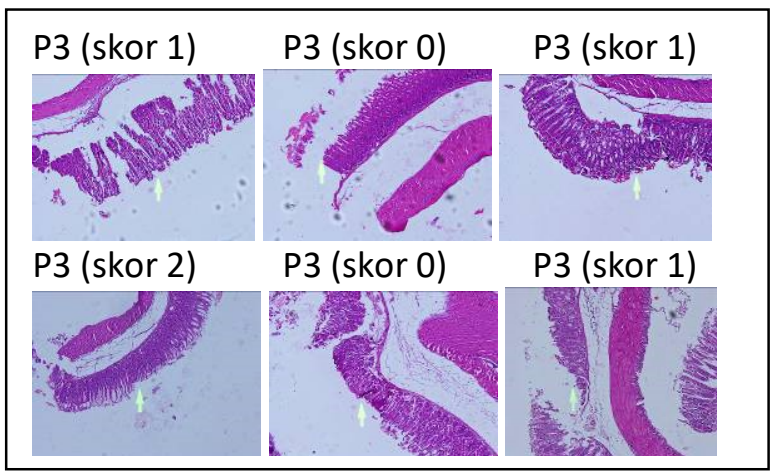

Gambar 4. Kelompok perlakuan 3 (P3)

Gambar 4 terlihat gambaran mikroskopis mukosa lambung mulai normal, karena sudah mengalami pengurangan kerusakan, dibandingkan dengan kelompok K, P1, dan P2. Hanya ada beberapa dengan skor integritas 1 (Deskuamasi epitel).

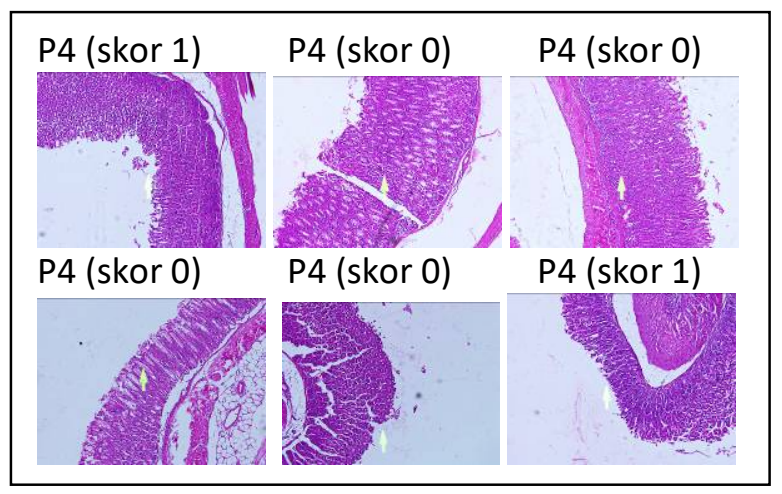

Gambar 5. Kelompok perlakuan 4 (P4)

Gambar 5 menunjukkan mukosa lambung dari semua kelompok perlakuan 4 sudah normal dengan skor integritas rerata 0 , dimana hanya beberapa yang mengalami kerusakan pada 1/3 lapisan atas epitel mukosa lambung terlepas. Tidak ditemukan skor 2 (erosi epitel/kerusakan sebagian mukosa lambung) dan skor 3 (ulserasi epitel), bila dibandingkan dengan kelompok K, P1, P2, P3 yang mana masih ditemukan deskuamasi epitel dan ulserasi.
Tabel 1. Integritas mukosa lambung untuk masingmasing kelompok

\begin{tabular}{|c|c|c|c|c|c|c|c|}
\hline \multirow[t]{3}{*}{ Grup } & \multirow[t]{3}{*}{ No } & \multicolumn{5}{|c|}{ Skor Integritas Mukosa } & \multirow[t]{3}{*}{ Rerata } \\
\hline & & LP & LP & LP & LP & LP & \\
\hline & & 1 & 2 & 3 & 4 & 5 & \\
\hline & 1 & 2 & 1 & 2 & 1 & 3 & 1.6 \\
\hline \multirow[t]{6}{*}{$(\mathrm{K})$} & 2 & 1 & 1 & 2 & 1 & 1 & 1.4 \\
\hline & 3 & 2 & 0 & 2 & 2 & 3 & 1.8 \\
\hline & 4 & 3 & 3 & 2 & 2 & 2 & 2.4 \\
\hline & 5 & 1 & 2 & 2 & 1 & 1 & 1.4 \\
\hline & 6 & 3 & 2 & 0 & 2 & 2 & 1.8 \\
\hline & 1 & 1 & 2 & 0 & 0 & 2 & 1 \\
\hline \multirow[t]{6}{*}{ (P1) } & 2 & 3 & 1 & 1 & 1 & 2 & 1.6 \\
\hline & 3 & 1 & 1 & 2 & 1 & 1 & 1.2 \\
\hline & 4 & 1 & 1 & 2 & 0 & 2 & 1.2 \\
\hline & 5 & 2 & 0 & 0 & 1 & 1 & 0.8 \\
\hline & 6 & 1 & 1 & 1 & 0 & 2 & 1 \\
\hline & 1 & 1 & 2 & 0 & 1 & 2 & 1.2 \\
\hline \multirow[t]{6}{*}{ (P2) } & 2 & 0 & 2 & 2 & 0 & 1 & 1 \\
\hline & 3 & 3 & 0 & 1 & 2 & 2 & 1.6 \\
\hline & 4 & 2 & 0 & 1 & 0 & 0 & 0.6 \\
\hline & 5 & 2 & 1 & 2 & 2 & 0 & 1.4 \\
\hline & 6 & 0 & 1 & 3 & 1 & 1 & 1.2 \\
\hline & 1 & 0 & 2 & 1 & 0 & 1 & 0.8 \\
\hline \multirow[t]{6}{*}{ (P3) } & 2 & 0 & 0 & 2 & 1 & 0 & 0.6 \\
\hline & 3 & 0 & 0 & 1 & 1 & 1 & 0.6 \\
\hline & 4 & 2 & 1 & 0 & 2 & 2 & 1.4 \\
\hline & 5 & 0 & 0 & 2 & 1 & 0 & 0.6 \\
\hline & 6 & 0 & 2 & 2 & 1 & 0 & 1 \\
\hline & 1 & 1 & 1 & 0 & 0 & 1 & 0.6 \\
\hline \multirow[t]{5}{*}{ (P4) } & 2 & 1 & 0 & 0 & 0 & 0 & 0.2 \\
\hline & 3 & 0 & 2 & 0 & 0 & 0 & 0.4 \\
\hline & 4 & 0 & 1 & 0 & 0 & 0 & 0.2 \\
\hline & 5 & 1 & 0 & 0 & 0 & 0 & 0.2 \\
\hline & 6 & 1 & 1 & 1 & 0 & 1 & 0.8 \\
\hline
\end{tabular}

Pada Tabel 1 terlihat perbedaan integritas mukosa lambung antar kelompok, yaitu kelompok kontrol yang hanya diinduksi Aspirin memiliki skor kerusakan mukosa lebih tinggi dibandingkan kelompok perlakuan 1, 2, 3 dan 4. Skor kerusakan mukosa yang 
tertinggi ditemukan pada kelompok kontrol sampel 4 sedangkan kerusakan mukosa paling rendah ditemukan pada kelompok perlakuan perlakuan 4 sampel 2.

Tabel 2. Rerata integritas mukosa tiap kelompok

\begin{tabular}{cc}
\hline Kelompok & Rerata \pm SD \\
\hline Kontrol & $1.73 \pm 0.37$ \\
Perlakuan 1 & $1.13 \pm 0.27$ \\
Perlakuan 2 & $1.16 \pm 0.34$ \\
Perlakuan 3 & $0.83 \pm 0.32$ \\
Perlakuan 4 & $0.40 \pm 0.25$ \\
\hline
\end{tabular}

Analisis data dilakukan untuk dapat mengetahui efektivitas kombinasi ekstrak kunyit (Curcuma Domestica $\mathrm{Val}$ ) dan madu terhadap perbaikan ulkus lambung mencit akibat pemberian aspirin serta signifikansi antarkategori yang diteliti. Pengujian yang pertama dilakukan adalah uji normalitas data menggunakan Shapiro Wilk test, diperoleh bahwa distribusi data normal ( $p>0.05)$ yaitu dengan nilai 0.195 yang berarti memenuhi syarat uji parametrik. Uji ini untuk mengetahui bermakna atau tidaknya perbedaan rerata skor integritas mukosa lebih dari dua kelompok menggunakan uji One Way ANOVA dan diperoleh perbedaan yang bermakna $(p<0.05)$ yaitu dengan nilai signifikansi 0.000. Kemaknaan untuk masing-masing kelompok kemudian dianalisis dengan uji post-hoc yaitu Tukey HSD.

Tabel 3. Hasil perhitungan uji post hoc $(\alpha=0,05)$ antar kelompok

\begin{tabular}{ccc}
\hline Kelompok & $\mathbf{p}$ & Kemaknaan \\
\hline P1 vs K & 0.003 & Signifikan \\
P2 vs K & 0.005 & Signifikan \\
P3 vs K & 0.000 & Signifikan \\
P4 vs K & 0.000 & Signifikan \\
P1 vs P2 & 0.856 & Tidak Signifikan \\
P3 vs P1 & 0.112 & Tidak Signifikan \\
P3 vs P2 & 0.079 & Tidak Signifikan \\
P4 vs P1 & 0.000 & Signifikan \\
P4 vs P2 & 0.000 & Signifikan \\
P4 vs P3 & 0.025 & Signifikan \\
\hline
\end{tabular}

Uji post hoc didapatkan pada kelompok P1, P2, P3 dan P4 dibandingkan dengan $\mathrm{K}$ dan begitu juga P4 dibandingkan dengan P3, P2, P1 menunjukkan hasil yang signifikan $(p<0.05)$, sedangkan P3 dibandingkan dengan P2 dan P1 menunjukkan hasil tidak signifikan $(p>0.05)$.

\section{PEMBAHASAN}

Penelitian dimulai dengan melakukan ekstraksi pada rimpang kunyit. Hasil ekstraksi didapat $220 \mathrm{mg}$ ekstrak kunyit dari 2 kg rimpang kunyit segar. Hal ini berbeda dengan penelitian yang dilakukan oleh Wahyuni et al (2004) menunjukkan hasil kurkumin lebih banyak didapatkan, ini bisa karena waktu ekstraksi yang berbeda, dimana waktu ekstraksi pada penelitian Wahyuni lebih lama sekitar 75 menit. $^{8}$ Dosis ekstrak kunyit yang digunakan pada penelitian ini berdasarkan penelitian sebelumnya oleh Adita (2010) yaitu $10 \mathrm{mg} / 20 \mathrm{gBB}{ }^{6}$

Penelitian selanjutnya melakukan percobaan ke semua mencit selama 3 hari, dimana pada semua mencit dimulai pemberian aspirin, kemudian setiap kelompok ada yang diberi madu, ekstrak kunyit dan kombinasi ekstrak kunyit dan madu. Setelah 3 hari perlakuan, mencit dikorbankan dan diambil lambung untuk dilihat gambaran histopatologinya, yang dinilai adalah integritas mukosa berdasarkan modifikasi kriteria Barthel Manja untuk menentukan apakah terjadi ulkus lambung. Pada penelitian ini tidak didapatkan mencit yang mati. Dosis aspirin 5,2 mg/BB yang diberikan selama 3 hari sudah menyebabkan terjadinya ulkus lambung pada mencit yang terbukti dari pra-penelitian.

Pada kelompok kontrol (K) memperlihatkan rerata terjadi ulkus lambung, skor rerata kerusakan mukosa lambung lebih tinggi dari kelompok perlakuan 1, 2, 3 dan 4. Hal ini sejalan dengan penelitian Adita (2010) dari segi lama pemberian aspirin menunjukkan bahwa pemberian aspirin selama 3 hari berturut-turut menyebabkan ulkus lambung pada mencit. ${ }^{6}$ Tetapi bila dilihat dari besar dosis $5.2 \mathrm{mg} / \mathrm{gBB}$ dibandingkan dengan dosis oleh Adita yaitu $1 \mathrm{mg} / \mathrm{gBB}$ didapatkan tidak sejalan, diduga adanya perbedaan biologis mencit dan adanya kemungkinan kandungan aspirin yang sudah tidak murni, karena yang digunakan tidak aspirin murni tetapi aspirin sediaan tablet. ${ }^{9}$

Pada kelompok perlakuan 1 (P1), berdasarkan uji statistik pada uji Post Hoc LSD didapatkan perbedaan signifikan $(p<0.05)$ antara kelompok P1 
dengan kontrol (p) 0.003. Data ini sesuai dengan penelitian Adita (2010) menunjukkan hasil yang sama dapat memproteksi mukosa lambung. Ekstrak kunyit memiliki beberapa zat yang terkandung (minyak atsiri \& kurkuminoid) dapat mencegah ulkus lambung. ${ }^{6}$

Pada kelompok perlakuan 2 (P2), berdasarkan hasil uji statistik pada penelitian ini, uji Post Hoc LSD didapatkan hasil yang signifikan $(p<0,05)$ antara kelompok P2 dengan kelompok kontrol (p) 0,005, dan kelompok P2 dengan P1 (p) 0,000. Didapatkan penurunan terjadinya ulkus lambung. Data ini sejalan dengan penelitian oleh Mustaba (2012) tentang studi histopatologi lambung yang diberi madu sebagai pencegah ulkus lambung yang diinduksi aspirin, didapatkan hasil pengurangan derajat kerusakan mukosa lambung mencit yang signifikan pada kelompok ulkus yang diberi madu apabila dibandingkan dengan kelompok ulkus yang tidak diberi madu. $^{7}$

Pada kelompok perlakuan 3 (P3), Berdasarkan uji post hoc LSD hasil yang signifikan terdapat antara kelompok P3 dengan $\mathrm{K}$ (p) 0,000, dan kelompok P3 dengan P4 (p) 0,025, sementara antara kelompok P3 dengan P1 dan P2 menunjukkan hasil yang tidak signifikan. Ternyata, pemberian kombinasi larutan ekstrak kunyit dan madu pada dosis yang sama dengan dosis madu atau larutan ekstrak kunyit saja tidak menunjukkan perbaikan ulkus lambung yang bermakna dibandingkan dengan yang menggunakan larutan ekstrak kunyit atau madu saja, tetapi dengan peningkatan dosis kombinasi larutan ektrak kunyit dan madu menunjukkan perbedaan yang bermakna. Penelitian yang dilakukan oleh Crysman et al (2014) membuktikan bahwa pemberian kunyit dan madu memilkiki efek yang sama dalam penyembuhan luka pada mencit. Hal ini disebabkan senyawa pada kunyit dan madu memiliki sifat antiinflamasi, dapat mempercepat re-epitelisasi, proliferasi sel dan sebagai antioksidan. $^{10,11,13}$

Pada kelompok perlakuan 4 (P4), berdasarkan hasil uji statistik didapatkan skor rerata integritas mukosa lambung 0 (normal). Keadaan ini menunjukkan tingkat penyembuhan terbesar ada pada ulkus lambung. Efektivitas kombinasi larutan ekstrak kunyit dan madu sangat baik dalam mengurangi ulkus lambung akibat pemberian aspirin. Hal ini karena dosis kombinasi ekstrak kunyit dan madu yang ditingkatkan.

Penelitian yang dilakukan oleh Prabu et al (2015) tentang Efek Sinergisme dan Aktivitas Antimikroba dari Kunyit dan Madu. Pada penelitian tersebut didapat kombinasi kunyit dan madu dapat meningkatkan aktivitas sebagai antimikroba. ${ }^{12}$

Berdasarkan hasil uji statistik, maka pada penelitian ini didapatkan, pada kelompok P3 jika dibandingkan dengan kelompok P2 dan P1 menunjukkan perbedaan yang tidak signifikan, tetapi pada kelompok P4 dibandingkan dengan P3, P2 dan P1 menunjukkan perbedaan yang signifikan. Jadi, pada penelitian ini kombinasi larutan ekstrak kunyit (30 $\mathrm{mg} / 20 \mathrm{gBB})$ dan madu $(0,12 \mathrm{ml} / 20 \mathrm{gBB})$ menunjukkan efektivitas yang paling baik dalam mengurangi ulkus lambung mencit akibat pemberian aspirin dibandingkan dengan yang diberi kombinasi larutan ekstrak kunyit (10 mg/20gBB) \& madu (0,04 $\mathrm{ml} / 20 \mathrm{gBB}$ ), dan hanya diberi larutan ekstrak kunyit atau madu saja.

\section{SIMPULAN}

Tidak terdapat perbedaan pengurangan ulkus lambung mencit pada dosis kombinasi kunyit (10mg/20gBB) dan madu $(0,04 \mathrm{ml} / 20 \mathrm{gBB})$, jika dibandingkan dengan menggunakan larutan ekstrak kunyit atau madu saja dengan dosis yang sama.

Pada dosis kombinasi larutan ekstrak kunyit (30 $\mathrm{mg} / 20 \mathrm{gBB})$ dan madu $(0,12 \mathrm{ml} / 20 \mathrm{gBB})$ menunjukkan perbaikan ulkus lambung mencit yang bermakna dibandingkan dengan dosis kombinasi larutan ekstrak kunyit $(10 \mathrm{mg} / 20 \mathrm{gBB})$ dan madu $(0,04 \mathrm{ml} / 20 \mathrm{gBB})$.

\section{UCAPAN TERIMA KASIH}

Terima kasih kepada semua pihak atas bimbingan, bantuan dan motivasi dalam penelitian ini serta semua pihak lainnya yang telah memberikan kontribusi dalam pelaksanaan penelitian ini. 


\section{DAFTAR PUSTAKA}

1. Wilmana F, Gan S. Farmakologi dan terapi, Edisi ke-5. Jakarta: Departemen Farmakologi dan Terapeutik Fakultas Kedokteran Universitas Indonesia. 2012. hlm.230-1, 233-7.

2. Katar Y. Aspek baru meningkatkan ulkus usus intestin akibat terapi dengan obat rematik anti inflamasi non steroid. Dalam: Prosiding Kongres Nasional Ikatan Farmakologi Indonesia. Batu Malang; 2000.

3. Staf Pengajar Departemen Farmakologi Fakultas Kedokteran Universitas Sriwijaya. Kumpulan kuliah farmakologi. Edisi ke-2. Jakarta: EGC; 2008.

4. Schellack N. An overview of gastropathy induced by nonsteroidal anti-inflammatory drugs. Journal $\mathrm{S}$ Afr Pharm. 2012;79(4):12-8.

5. Waranugraha $\mathrm{Y}$, Suryana BPP, Pratomo B. Relationship of NSAID utilization pattern with gastropathy symptoms in rheumatic patient. Jurnal kedokteran Brawijaya. 2010;26(2):80-9.

6. Adita F. Pengaruh pemberian kunyit (Curcuma domestica val) terhadap kerusakan histologi mukosa gaster mencit (Mus musculus) yang diinduksi aspirin (skripsi). Surakarta: Fakultas Kedokteran Universitas Sebelas Maret; 2010.

7. Mustaba R. Studi histopatologi lambung pada tikus putih yang diberi madu sebagai pencegah ulkus lambung yang diinduksi aspirin. Jurnal Indonesia Medicus Veterinus. 2012;1(4):471-82.

8. Wahyuni A, Hardjono, Paskalina HY. Ekstraksi kurkumin dari kunyit. Dalam: Prosiding Seminar Nasional Rekayasa Kimia dan Prose S. Yogyakarta. 2004.ISSN:1411-4216.

9. Lelo A, Hidayat DS, Juli S. Penggunaan antiinflamasi non-steroid yang rasional pada penanggulangan nyeri rematik. Medan: e-USU; 2004.

10.Chrysman, Prahasrum S, Evacuasiany E. Comparison of effect extract tumeris ( Curcuma domestica val) \& honey (Mel deporatum) against healing on mice male Swiss webster (skripsi). Fakultas Kedokteran Universitas Kristen Maranarha; 2014.

11.Moruk AKO, Wigunaningsih W, Salam A, Uleander $B$, Hernawardi. Madu obat dan suplemen. Bali: Pak Oles Centre; 2006.

12.Prabu B, Gorakh MSD, Harjinder S. Synergitis and addictive antimirobial activitis of curcumin, manuka honey an whey proteins. Journal of Food Biochemidtry. 2015; ISSN 1745-4514.

13. Winarto WP. Khasiat dan manfaat kunyit. Jakarta: Agromedia Pustaka Tim Lentara. 2004. hlm. 23-32. 